\title{
PENGEMBANGAN PERANGKAT PEMBELAJARAN IPA SMP DENGAN MODEL INKUIRI UNTUK MELATIHKAN KETERAMPILAN PROSES PADA MATERI SISTEM PENCERNAAN MANUSIA
}

\author{
Antika Yekti Handayani'), Mohamad Nur'), Yuni Sri Rahayu ${ }^{3)}$ \\ ${ }^{1)}$ Mahasiswa Program Studi Pendidikan Dasar, Program Pascasarjana Universitas Negeri Surabaya \\ ${ }^{2), 3)}$ Dosen Pascasarjana Prodi Pendidikan Sains Univesrtitas Negeri Surabaya \\ E-mail: antikayekti@gmail.com
}

\begin{abstract}
Science process learning emphasis on giving learning experience directly to develop competence in exploring and understanding environment scientifically. Science education is purposed for inquiry and do something in order to help the student to get more understanding about environment. The purpose of this development research is to describe the validity, practicality, and effectiveness of science-biology teaching learning package for Junior High School using inquiry model to facilitate science process skills in human digestive system matter. The package was developed using a 4-D model, and it was implemented in 30 students of SMPN 2 Lamongan. The design of this implementation phase was One Group Pretest Posttest Design with a descriptive analysis of data. The validation revealed that the package was in good quality, so it fits to be used as a teaching learning package. Enforceability of lesson plans was also well-categorized. The student's activities showed the appropriate inquiry learning. The student achievement in pretest was all students not complete, in posttest all students was complete. Average cognitive product were 49,11 and 91,11 in pretest and posttest respectively with N-Gain 0,82 . Average cognitive process were 17,46 and 93,73 respectively with $\mathrm{N}$-Gain 0,92 . N-Gain analysis results illustrate that the model of inquiry learning process was able to improve students' science process skills because the result obtained are in the high category. Inquiry learning model also influenced students' cognitif leaning outcome, which could complete all aspect of learning objectives. Sensitivity items were between 0,3 up to 1,0 . This indicates that all items were sensitive to learning effect. The student respond of this learning was good, and the students were really exciting and this model could facilitate them to learn. The conclusions of this research was the learning package using inquiry model was valid, practise, and effective to improve students' science process skills in human digestive system.
\end{abstract}

Keywords: Inquiry learning model and science process skills

\begin{abstract}
Abstrak: Proses pembelajaran IPA menekankan pada pemberian pengalaman belajar secara langsung untuk mengembangkan kompetensi dalam menjelajahi dan memahami alam sekitar secara ilmiah. Pendidikan IPA diarahkan untuk inkuiri dan berbuat sehingga membantu peserta didik untuk memperoleh pemahaman yang lebih mendalam tentang alam sekitar. Penelitian pengembangan yang telah dilakukan bertujuan untuk mendeskripsikan validitas, kepraktisan, dan efektifitas perangkat pembelajaran IPA yang dikembangkan dengan model inkuiri untuk melatihkan keterampilan proses pada materi sistem pencernaan manusia. Jenis penelitian yang digunakan adalah penelitian pengembangan dengan menggunakan model pengembangan perangkat 4-D, uji coba II pada 30 siswa SMPN 2 Lamongan. Rancangan penelitian saat uji coba adalah One Group Pretest-Posttest. Design dengan analisis data secara deskriptif. Hasil validasi menunjukkan bahwa perangkat berkualitas baik, sehingga layak digunakan dalam pembelajaran, keterlaksanaan RPP dikategorikan baik, dan aktivitas siswa sesuai dengan model pembelajaran inkuiri. Hasil belajar siswa pada uji awal (pretest) menunjukkan semua siswa tidak ada yang tuntas, sedangkan pada uji akhir (posttest) semua siswa tuntas. THB produk rata-rata uji awal (pretest) 49,11 dan rata-rata uji akhir (posttest) 91,11 dengan Indeks N-Gain 0,82. THB proses rata-rata uji awal (pretest) 17,46 dan rata-rata uji akhir (posttest) 93,73 dengan Indeks N-Gain 0,92. Hasil analisis N-Gain menunjukkan bahwa model pembelajaran inkuiri dapat melatihkan keterampilan proses siswa, karena hasil yang diperoleh berada pada kategori tinggi. Sensitivitas butir soal seluruhnya menunjukkan peka terhadap efek pembelajaran karena berada antara 0,3 sampai dengan 1,0. Respon siswa terhadap pembelajaran dinilai baru, menarik, dan memudahkan siswa dalam belajar. Simpulan penelitian ini adalah perangkat pembelajaran yang dikembangkan dengan model inkuiri adalah valid, praktis dan efektif untuk melatihkan keterampilan proses pada materi sistem pencernaan manusia.
\end{abstract}

Kata kunci: Pembelajaran inkuiri dan keterampilan proses. 


\section{PENDAhuluan}

Carin dan Sund (1993) dalam Depdiknas (2007) menjelaskan hakikat IPA terdiri 4 unsur utama: (1) sikap, yaitu rasa ingin tahu tentang benda, fenomena alam, makhluk hidup, serta hubungan sebab akibat yang menimbulkan masalah baru yang dapat dipecahkan melalui prosedur yang benar; IPA bersifat open ended. (2) Proses, yaitu prosedur pemecahan masalah melalui metode ilmiah yang meliputi penyusunan hipotesis, perancangan eksperimen atau percobaan, evaluasi, pengukuran, dan penarikan kesimpulan. (3) Produk berupa fakta, prinsip, teori, dan hukum. (4) Aplikasi, yaitu penerapan metode ilmiah dan konsep IPA dalam kehidupan sehari-hari. Keempat unsur itu merupakan ciri sains yang utuh yang tidak dapat dipisahkan satu sama lain. Dalam proses pembelajaran sains keempat unsur itu diharapkan dapat muncul sehingga peserta didik dapat mengalami proses pembelajaran yang utuh dan dapat bermanfaat untuk mengatasi permasalahan hidupnya.

Kecenderungan di sekolah memperlihatkan bahwa Peserta didik hanya mempelajari sains sebagai produk, menghafal konsep, teori dan hukum, pembelajarannya berorientasi pada tes atau ujian. Akibatnya sains sebagai proses, sikap, dan aplikasi tidak tersentuh dalam pembelajaran. Pembelajaran lebih bersifat teachercentered, Guru hanya menyampaikan IPA sebagai produk dan siswa menghafal informasi aktual sedangkan penguasaan sikap dan keterampilan siswa dalam belajar belum mendapat perhatian yang memadai.

Siswa tidak dibiasakan untuk berkembang secara mandiri melalui penemuan dan proses berpikirnya. Cara berpikir yang dikembangkan dalam kegiatan belajar belum menyentuh domain afektif dan psikomotor. Alasan yang sering dikemukakan oleh para guru adalah keterbatasan waktu, sarana, lingkungan belajar, dan jumlah peserta didik per kelas yang terlalu banyak (Depdiknas, 2007).

Menurut Collete dan Chiapetta (1994:89), keterampilan proses sains adalah kemampuan dalam melaksanakan tahap-tahap percobaan, yang merupakan keterampilan proses terpadu meliputi keterampilan merumuskan masalah, menyusun hipotesis, menentukan variabel percobaan, merancang percobaan, mengumpulkan data, menganalisis data, dan merumuskan kesimpulan. Gulo (2002) menyatakan bahwa keterampilan inkuiri merupakan suatu proses yang berawal dari merumuskan masalah, menyusun hipotesis, mengumpulkan data, menganalisis data, dan membuat kesimpulan. Dengan demikian, untuk melatihkan keterampilan proses sains, dapat digunakan model pembelajaran inkuiri.
Hasil penelitian Dini Indriani (2013) menemukan bahwa penggunaan model inkuiri terbimbing dalam pembelajaran biologi efektif untuk menuntaskan hasil belajar siswa pada bahan kajian sistem pencernaan makanan pada manusia.

Tujuan dalam penelitian ini adalah untuk mendeskripsikan kelayakan perangkat pembelajaran IPA SMP dengan model inkuiri untuk melatihkan keterampilan proses pada materi sistem pencernaan manusia. Tujuan penelitian ini dirinci menjadi beberapa tujuan khusus sebagai berikut:

1. Mendeskripsikan validitas perangkat pembelajaran IPA yang dikembangkan dengan model inkuiri untuk melatihkan keterampilan proses pada materi sistem pencernaan manusia.

2. Mendeskripsikan kepraktisan perangkat pembelajaran IPA yang dikembangkan dengan model inkuiri untuk melatihkan keterampilan proses pada materi sistem pencernaan manusia.

Menjelaskan keterlaksanaan Rencana Pelaksanaan Pembelajaran IPA yang dikembangkan dengan model inkuiri untuk melatihkan keterampilan proses pada materi sistem pencernaan manusia.

3. Mendeskripsikan efektivitas pembelajaran IPA yang dikembangkan dengan model inkuiri untuk melatihkan keterampilan proses pada materi sistem pencernaan manusia.

a. Menjelaskan aktivitas siswa dalam kegiatan pembelajaran yang menggunakan pembelajaran IPA yang dikembangkan dengan model inkuiri untuk melatihkan keterampilan proses pada materi sistem pencernaan manusia.

b. Menjelaskan respon siswa terhadap kegiatan pembelajaran IPA yang dikembangkan dengan model inkuiri untuk melatihkan keterampilan proses pada materi sistem pencernaan manusia.

c. Menilai ketuntasan hasil belajar siswa setelah dilakukan pembelajaran menggunakan perangkat pembelajaran dengan model inkuiri untuk melatihkan keterampilan proses pada materi sistem pencernaan manusia.

4. Mendeskripsikan kendala-kendala yang ditemukan dalam pelaksanaan pembelajaran IPA yang dikembangkan dengan model inkuiri untuk melatihkan keterampilan proses pada materi sistem pencernaan manusia.

\section{METODE PENELITIAN}

Jenis penelitian ini merupakan penelitian pengembangan (development research). Perangkat pembelajaran yang dikembangkan meliputi: Silabus, Rencana Pelaksanaan Pembelajaran (RPP), Lembar 
Kerja Siswa (LKS), Bahan Ajar Siswa (BAS), Lembar Penilaian Tes Hasil Belajar (THB) kognitif dan THB keterampilan proses pada materi sistem pencernaan manusia. Subjek penelitian adalah perangkat pembelajaran dengan model inkuiri untuk melatihkan keterampilan proses pada materi sistem pencernaan manusia, yang diujicobakan pada siswa kelas VIII SMP Negeri 2 Lamongan tahun pelajaran 2013-2014. Penelitian ini dilaksanakan di SMP Negeri 2 Lamongan tanggal 10-24 Mei 2014 sebanyak tiga kali pertemuan ditambah pretest dan posttest.

Tahap pengembangan perangkat dilaksanakan dalam 3 (tiga) tahap, mengacu pada Model 4-P yang diadaptasi dari Model 4-D Thiagarajan, yaitu: (1) Tahap Pendefinisian, (2) Tahap Perancangan Perangkat, dan (3) Tahap Pengembangan Perangkat Pembelajaran. Rancangan penelitian ini menggunakan model One Group Pretest-Posttest Design, yaitu desain yang diterapkan pada suatu kelompok, tanpa kelompok pembanding (kontrol), dengan rumusan desain sebagai berikut:

\section{$\mathbf{U}_{1} \times \mathbf{U}_{2}$}

Keterangan :

$\mathrm{U}_{1}=\mathrm{Uji}$ awal (pretest), berupa tes kognitif dan tes keterampilan proses untuk mengetahui kemampuan awal siswa

$\mathrm{x}=$ Perlakuan, yaitu proses pembelajaran yang menerapkan perangkat pembelajaran dengan metode inkuiri untuk melatihkan keterampilan proses pada materi sistem pencernaan pada manusia.

$\mathrm{U}_{2}=\mathrm{Uji}$ akhir (posttest) berupa tes kognitif dan tes keterampilan proses untuk mengetahui penguasaan materi siswa setelah penerapan perangkat pembelajaran.

Perbedaan jumlah siswa yang tuntas pada $U_{1}$ (pretest) dan $\mathrm{U}_{2}$ (posttest) diasumsikan merupakan efek dari perlakuan yang diberikan (Arikunto, 2010). Instrumen dalam penelitian ini terdiri lembar validasi, lembar pengamatan aktivitas siswa, lembar penilaian (THB kognitif dan THB keterampilan proses), angket respon siswa, lembar pengamatan kendala pembelajaran.

Teknik Pengumpulan Data pada penelitian ini adalah observasi atau pengamatan, pemberian tes, pemberian angket, validasi pakar. Data yang dianalisis adalah data validasi perangkat pembelajaran, data keterlaksanaan RPP, data tes hasil belajar siswa, sensitivitas butir soal, ketuntasan indikator, ketuntasan individual, analisis data aktivitas siswa, analisis angket respon siswa, analisis data kendala-kendala dalam pembelajaran.

\section{HASIL PENELITIAN DAN DISKUSI}

Skor rata-rata yang diberikan oleh kedua validator untuk kualitas silabus yang telah dikembangkan sebesar 3,51 sehingga secara umum memberikan penilaian dengan kategori baik. Pencapaian kualitas ini karena pada saat mengembangkan silabus, peneliti memperhatikan Peraturan Pemerintah No. 19 Tahun 2005 tentang Standar Nasional Pendidikan dan Permendiknas No. 41 Tahun 2007 tentang Standar Proses yang menyatakan bahwa perencanaan proses pembelajaran terdiri silabus dan RPP, yang memuat: identitas mata pelajaran, Standar Kompetensi, Kompetensi Dasar, indikator pencapaian kompetensi, tujuan pembelajaran, materi ajar, alokasi waktu, metode pembelajaran, penilaian hasil belajar, dan sumber belajar. Silabus yang dikembangkan peneliti juga memuat komponen-komponen tersebut. Berdasarkan hasil validasi dan revisi dari validator, dihasilkan silabus final yang akan peneliti gunakan sebagai pedoman dalam pengembangan perangkat pembelajaran lebih lanjut, seperti: pembuatan RPP, pengelolaan kegiatan pembelajaran dan pengembangan sistem penilaian sesuai dengan yang dituliskan dalam Panduan Pengembangan Silabus (Depdiknas, 2008).

Berdasarkan pendapat Nur (2008) bahwa RPP yang dikembangkan dengan berbasis teori belajar yang tepat, penggunaan strategi dan model pembelajaran yang bervariasi akan mengaktifkan peserta didik. Pemilihan pembelajaran model kooperatif pada pertemuan pertama sesuai dengan yang dikemukakan Nur (2008:8) bahwa siswa lebih mudah menemukan dan memahami konsep-konsep sulit jika mereka saling mendiskusikan masalah tersebut dengan temannya.

Dengan model pembelajaran kooperatif siswa bekerja dalam kelompok untuk saling membantu memecahkan masalah-masalah yang kompleks. Sedangkan Vygotsky dalam Arend (2007:47) menjelaskan bahwa interaksi sosial dengan orang lain memacu pengkontruksian ide-ide baru dan meningkatkan perkembangan intelektual siswa. Dengan bantuan yang tepat dari guru dan teman sebaya yang lebih mampu, siswa maju ke zone of proximal development tempat pembelajaran terjadi. Berdasarkan teori ini disarankan untuk menggunakan kelompokkelompok belajar dengan kemampuan anggota kelompok yang berbeda-beda untuk mengupayakan pembelajaran.

Pada RPP yang dikembangkan melatihkan beberapa keterampilan proses, yaitu: merumuskan masalah, menyusun hipotesis, menentukan variabel 
percobaan, merancang percobaan, mengumpulkan data, menganalisis data, dan merumuskan kesimpulan.

Hal ini sesuai dengan Collette dan Chiapetta (1994:89) yang menyatakan bahwa keterampilan proses sains adalah kemampuan dalam melaksanakan tahaptahap percobaan, antara lain: merumuskan masalah, menyusun hipotesis, menentukan variabel percobaan, merancang percobaan, mengumpulkan data, menganalisis data, dan merumuskan kesimpulan. Pada pertemuan kedua dan ketiga RPP yang dikembangkan menggunakan model inkuiri untuk melatihkan keterampilan proses dengan melakukan eksperimen. Hal ini sesuai dengan The National Research Council (2000:13-14) bahwa pembelajaran inkuiri merupakan model pembelajaran yang berorientasi pada proses dan keahlian untuk melakukan kegiatan penelitian, di dalamnya melibatkan bermacam-macam aktivitas, misalnya melakukan observasi, bertanya, menguji hipotesis, dan membuktikan dengan eksperimen, menggunakan alat-alat, menganalisis dan menginterpretasi data, mengusulkan jawaban, menjelaskan dan memprediksi, serta mempresentasikan hasilnya.

Skor rata-rata hasil validasi RPP dari dua validator adalah 3,56. Secara umum validator memberikan penilaian dengan kategori baik. Pencapaian kualitas ini dikarenakan pengembangan RPP ini peneliti mengacu pada Peraturan Pemerintah No. 19 Tahun 2005 tentang Standar Nasional Pendidikan yang menyebutkan bahwa perencanaan proses pembelajaran meliputi silabus dan RPP yang memuat sekurang-kurangnya tujuan pembelajaran, materi ajar, alokasi waktu, metode pembelajaran, penilaian hasil belajar, dan sumber belajar. Sistematika penyusunan RPP telah memenuhi komponen-komponen RPP sebagaimana yang tercantum dalam Permendiknas No. 41 tahun 2007 tentang standar proses yang menyebutkan bahwa komponen memuat identitas mata pelajaran, SK, KD, indikator pencapaian kompetensi, tujuan pembelajaran, materi ajar, alokasi waktu, metode pembelajaran, kegiatan pembelajaran, penilaian hasil belajar, dan sumber belajar.Dengan demikian, RPP yang telah dikembangkan dan direvisi ini layak untuk digunakan dalam pembelajaran.

LKS yang dikembangkan ini menggunakan model inkuiri, merupakan panduan siswa di dalam melakukan aktivitas penemuan. LKS ini lebih mengutamakan peran siswa dalam berinisiatif sendiri dan keterlibatan aktif dalam kegiatan pembelajaran. Peserta didik diberi kesempatan untuk melakukan eksperimen dengan objek fisik, yang ditunjang interaksi dengan teman sebaya dan bimbingan guru, hal ini dilakukan agar siswa tidak mengalami kesulitan dalam menggunakan kecakapan ilmiah dalam kegiatan penemuan. Hal ini sesuai dengan
Nur (2008:11) dalam pembelajaran inkuiri siswa didorong untuk belajar melalui keterlibatan aktif mereka sendiri dengan konsep-konsep dan prinsipprinsip dengan melakukan pengamatan atau percobaan yang memungkinkan mereka menemukan prinsipprinsip untuk mereka sendiri.

Permendiknas No 41 tahun 2007 menyatakan bahwa proses pembelajaran pada tingkat satuan pendidikan dasar dan menengah harus interaktif, inspiratif, menyenangkan, menantang, dan memotivasi peserta didik untuk berpartisipasi aktif, serta memberikan ruang yang cukup bagi prakarsa, kreativitas, dan kemandirian sesuai dengan bakat, minat, dan perkembangan fisik serta psikologis peserta didik. Berdasarkan hal tersebut, penyajian LKS pada pertemuan ketiga dilengkapi dengan media pembelajaran berupa simulasi PhET untuk membangkitkan motivasi dan rasa ingin tahu siswa. Menurut Eggen dan Kauchak (2012:189), meskipun simulasi tidak memberi siswa pengalaman langsung, tetapi simulasi lebih fleksibel dan interaktif sehingga dapat meningkatkan motivasi dan pemahaman siswa.

Bahan Ajar siswa (BAS) ini merupakan panduan siswa di dalam kegiatan pembelajaran yang berorientasi pada pendekatan pembelajaran inkuiri. Materi ajar yang dikembangkan diambil dari beberapa sumber dengan materi yang relevan dengan tingkat pendidikan SMP. BAS ini berisi materi tentang 1) sistem pencernaan pada manusia, 2) makanan dan fungsinya, 3) gangguan dan kelainan pada sistem pencernaan manusia. Skor ratarata BAS adalah 3,57. Secara umum validator memberikan penilaian dengan kategori baik dan dapat digunakan dengan sedikit revisi sebagai perangkat pembelajaran.

Pencapaian kualitas ini dikarenakan pengembangan BAS ini telah melalui beberapa tahapan, yaitu: studi literatur, pengkajian teori tentang aktivitas siswa pada pembelajaran inkuiri, pengkajian metode observasi yang sesuai dan telaah dari pembimbing. Berdasarkan masukan dari penelaah, revisi yang telah dilakukan pada buku siswa ini adalah melengkapi gambar-gambar pendukung yang bagus sehingga lebih menarik minat siswa untuk mempelajarinya.

Tes Hasil Belajar (THB) merupakan alat evaluasi untuk mengukur kemampuan kognitif siswa. Menurut Anderson dan Krathwol (2001), dimensi proses kognitif terbagi menjadi enam tingkatan, yaitu: mengingat $(\mathrm{C} 1)$, memahami (C2), menerapkan (C3), menganalisis (C4), mengevaluasi (C5), dan menciptakan (C6). Dengan mengacu pada taksonomi Bloom revisi ini soal yang dikembangkan terdiri dari : (a) Soal THB kognitif produk, terdiri dari: soal mengingat $(\mathrm{C} 1)$, yaitu nomor $1,4,11$, dan 12, soal memahami (C2), yaitu nomor 2, $6,7,9,10,13,14$, dan 15 , soal menerapkan (C3), yaitu 
nomor 3 dan 8, soal menganalisis (C4), yaitu nomor 5 . (b) Soal THB keterampilan proses, yaitu tes untuk mengukur kemampuan siswa pada aspek kognitif proses, yang meliputi kemampuan merumuskan masalah, menyusun hipotesis, mengidentifikasi variabel, menyusun definisi operasional variabel, menyusun prosedur percobaan, membuat tabel/grafik berdasar data percobaan, menganalisis data, dan menarik kesimpulan. Soal THB keterampilan proses, terdiri dari: soal memahami (C2), yaitu nomor 17, 18, dan 19, soal menerapkan (C3), yaitu nomor 16 dan 19, soal menganalisis (C4), yaitu nomor 21 dan 22.

Skor rata-rata hasil validasi THB kognitif adalah 3,70 untuk validasi isi dan 4 untuk bahasa dan penulisan soal. Secara umum validator memberikan penilaian dengan kategori sangat valid untuk validasi isi dan sangat dapat dipahami untuk bahasa dan penulisan soal. Skor rata-rata hasil validasi THB keterampilan proses adalah 3,64 untuk validasi isi dan 4 untuk bahasa dan penulisan soal. Secara umum validator memberikan penilaian dengan kategori sangat valid untuk validasi isi dan sangat dapat dipahami untuk bahasa dan penulisan soal. THB kognitif dan THB keterampilan proses ratarata berkategori sangat valid dan sangat mudah dipahami sehingga dapat digunakan dengan sedikit revisi sebagai perangkat pembelajaran.

Hasil analisis data menunjukkan bahwa pengelolaan pembelajaran dengan menggunakan model inkuiri untuk melatihkan keterampilan proses secara keseluruhan sudah terlaksana dengan baik. Pada kegiatan pendahuluan, kegiatan inti, penutup, pengelolaan waktu, dan pengamatan suasana kelas dalam kategori baik. Kondisi ini disebabkan kegiatan pembelajaran selalu mengacu pada RPP yang telah dipersiapkan secara matang, tersusun rapi dan berurutan. Hal ini sesuai dengan PP No. 19 Tahun 2005 pasal 19 ayat 3 setiap satuan pendidikan melakukan perencanaan proses pembelajaran, pelaksanaan pembelajaran, penilaian hasil belajar, dan pengawasan proses pembelajaran untuk terlaksananya proses pembelajaran yang efektif dan efisien.

Hal ini sesuai dengan pendapat Nur (2009) bahwa keterlaksanaan RPP didukung oleh ketersediaan perangkat pembelajaran yang berkualitas baik karena disusun secara sistematis, komprehensif dan solid dalam mencapai KD yang telah ditetapkan, sehingga akan memberi kemudahan bagi guru dan siswa dalam mengembangkan seluruh potensi siswa yang meliputi kognitif, psikomotorik, dan afektif. Dan salah satu faktor yang mempengaruhi kualitas pembelajaran adalah tersedianya perangkat pembelajaran yang disertai komitmen yang tinggi untuk melaksanakannya dalam setiap pembelajaran.
Hal ini dibuktikan dengan data bahwa dari 23 aspek yang diamati (RPP 1) dan 19 aspek yang diamati (RPP 2 dan 3) semua dapat dilakukan guru sehingga untuk keterlaksanaannya adalah 100\%. Ini akan berdampak pada respon siswa terhadap cara guru mengajar dan suasana belajar. Terbukti bahwa $80 \%$ siswa menyatakan tertarik dengan cara guru mengajar dan suasana belajar. Selain itu, juga berdampak pula pada hasil belajar kognitif maupun keterampilan proses. Pada uji coba 2 rata-rata nilai uji awal (pretest) kognitif siswa hanya sebesar 47,78 setelah dilakukan pembelajaran inkuiri rata-rata nilai uji akhir (posttest) kognitif siswa pada uji coba 2 dapat mencapai 91,11. Pada uji coba 2 rata-rata nilai uji awal (pretest) keterampilan proses siswa hanya sebesar 17,46 setelah dilakukan pembelajaran inkuiri rata-rata nilai uji akhir (posttest) keterampilan proses siswa pada uji coba 2 setelah dilakukan pembelajaran inkuiri dapat mencapai 93,73

Kemampuan guru dalam mengelola pembelajaran pada kegiatan pendahuluan dapat dilihat pada pertemuan $1(3,5)$, pertemuan $2(4,0)$, dan pertemuan 3 $(4,0)$. Skor rata-rata hasil pengamatan pada kegiatan pendahuluan 3,8 dengan kategori baik. Hal ini menunjukkan bahwa guru sudah membuka pelajaran dengan baik, menggunakan pertanyaan-pertanyaan yang didasarkan pada pengetahuan awal siswa untuk mengaitkan pengetahuan sebelumnya dengan materi yang akan dipelajari. Ini dilakukan untuk meningkatkan keingintahuan siswa sehingga siswa termotivasi untuk mengikuti kegiatan selanjutnya. Selain itu, guru juga menjelaskan tujuan pembelajaran yang akan dicapai setelah kegiatan pembelajaran dilaksanakan.

Kemampuan guru dalam mengelola pembelajaran pada kegiatan inti pada pertemuan $1(3,6)$, pertemuan 2 $(3,7)$, dan pertemuan $3(3,9)$. Skor rata-rata hasil pengamatan pada kegiatan inti 3,7 dengan kategori baik, karena guru mengelola pembelajaran dengan baik, membimbing siswa menyelesaikan tugas yang diberikan dan guru memberi dorongan agar siswa aktif dan terlibat langsung dalam proses pembelajaran. Hal ini sesuai dengan Arends (1997:373) yang menyatakan bahwa peran guru tidak hanya membagikan pengetahuan dan kebenaran namun juga berperan sebagai penuntun dan pemandu.

Pada prinsipnya, keseluruhan proses pembelajaran membantu siswa menjadi mandiri, percaya diri dan yakin pada kemampuan intelektualnya sendiri secara aktif. Kegiatan inti diakhiri dengan mengecek pemahaman siswa. Ini dilakukan untuk mengetahui pemahaman siswa terhadap materi yang telah diajarkan dan membuat siswa lebih perhatian. Menurut Galnzer dalam Nur (1998), rangsangan yang mendapat perhatian dan dikenali kemudian dipindahkkan ke short term 
memory (ingatan jangka pendek), suatu tempat penyimpanan yang memiliki kapasitas terbatas. Adanya serangkaian kerja mental berupa pengulangan, hafalan, dan pemecahan masalah, informasi tersebut dapat dipindahkan ke ingatan jangka panjang (long term memory).

Kemampuan guru dalam mengelola pembelajaran pada kegiatan penutup pada pertemuan $1(3,6)$, pertemuan $2(4,0)$, dan pertemuan $3(4,0)$. Skor rata-rata hasil pengamatan pada kegiatan penutup 3,9 dengan kategori baik. Pada kegiatan penutup guru bertindak sebagai pembimbing siswa dalam membuat rangkuman,memberikan tugas baik tugas individual maupun kelompok sesuai dengan hasil belajar yang ingin dicapai, dan menyampaikan rencana pembelajaran pada pertemuan berikutnya. Semua kegiatan yang telah diuraikan tersebut di atas telah terlaksana dengan baik.

Kemampuan guru dalam pengelolaan waktu pada pertemuan $1(3,5)$, pertemuan $2(3,5)$, dan pertemuan 3 $(4,0)$. Skor rata-rata hasil pengamatan kemampuan guru dalam pengelolaan waktu 3,7 dengan kategori baik. Ini dikarenakan adanya pembagian waktu yang jelas antara penggalan pertama dengan penggalan berikutnya memudahkan guru dalam mengalokasikan waktu dengan tepat. Sedangkan pengamatan suasana kelas pada pertemuan $1(3,6)$, pertemuan $2(3,7)$, dan pertemuan $3(3,8)$. Skor rata-rata hasil pengamatan kemampuan guru dalam pengelolaan waktu 3,7 dengan kategori baik. Hal ini menunjukkan bahwa guru mampu menciptakan susana yang menyenangkan, dapat meningkatkan minat dan motivasi siswa sehingga siswa mengikuti pembelajaran dengan antusias. Siswa akan belajar dengan baik apabila ada faktor pendorongnya (motivasi).

Para ahli psikologi, Baron (1992) dan Schunk (1990) dalam Nur (2008:2), mendefinisikan motivasi sebagai suatu proses internal (dari dalam diri seseorang) yang mengaktifkan, membimbing, dan mempertahankan perilaku dalam rentang waktu tertentu. Oleh karena itu, motivasi sangat penting dalam proses pembelajaran.

Menurut Collete dan Cipetta (1994) pembelajaran inkuiri membutuhkan guru yang dapat menumbuhkan lingkungan belajar yang dapat merangsang rasa ingin tahu siswa untuk melakukan penyelidikan. Hal ini dapat dibuktikan dengan tingginya aktivitas siswa dalam mengumpulkan data dengan melakukan percobaan $17,92 \%$. Peran guru yang positif ini juga terlihat dari respon siswa yang menunjukkan bahwa $80 \%$ siswa tertarik dengan cara guru mengajar dan suasana belajar. $80 \%$ siswa tertarik dengan penerapan model pembelajaran inkuiri untuk melatihkan keterampilan proses dan $100 \%$ tertarik pada penggunaan program simulasi PhET dalam pembelajaran. Ini dapat mengindikasikan bahwa kegiatan belajar mengajar berlangsung dengan baik sesuai dengan tujuan pembelajaran, penguasaan konsep baik, pembelajaran sesuai dengan sintaks yang digunakan, dengan suasana kelas yang menyenangkan siswa antusias mengikuti pembelajaran sehingga KBM berpusat pada siswa sedangkan guru berperan sebagai fasilitator.

Terlaksananya tahap-tahap dalam RPP menjadi salah satu faktor yang mendukung peningkatan hasil belajar siswa, baik pada kognitif maupun keterampilan proses. Rata-rata nilai uji awal (pretest) kognitif siswa pada uji coba 2 hanya sebesar 47,78 setelah dilakukan pembelajaran inkuiri rata-rata nilai uji akhir (posttest) kognitif siswa pada uji coba 2 dapat mencapai 91,11. Sedangkan rata-rata nilai nilai uji awal (pretest) keterampilan proses siswa pada uji coba 2 hanya sebesar 17,46 setelah dilakukan pembelajaran inkuiri untuk melatihkan keterampilan proses rata-rata nilai uji akhir (posttest) keterampilan proses siswa pada uji coba 2 dapat mencapai 93,73.

Rata-rata reliabilitas instrumen pengamatan aktivitas siswa pada uji coba 1 (pertemuan 1-3) adalah $96,84 \%$ sedangkan rata-rata reliabilitas instrumen pengamatan aktivitas siswa pada uji coba 2 (pertemuan 1-3) adalah 95,80\%. Data tersebut menunjukkan instrumen pengamatan aktivitas siswa memiliki reliabilitas yang tinggi karena melebihi 75\%. Reliabilitas ini menunjukan konsistensi keterlaksanaan pembelajaran apabila perangkat ini diujikan kedua kalinya yaitu pada ujicoba 2 dengan perangkat yang sama akan mendapatkan hasil yang relatif sama.

Persentase aktivitas siswa yang menonjol yang dilakukan pada pertemuan pertama adalah membaca bahan ajar siswa/LKS 13,02\%, mengerjakan tugas $13,75 \%$, menyampaikan ide/pendapat dalam diskusi kelompok 10,21\%, mencatat hasil diskusi kelompok $13,65 \%$, melibatkan diri dalam penyelesaian soal atau masalah untuk menerapkan konsep/prinsip/hukum/teori dalam situasi yang lain 10,31\%, dan bertanya pada guru 9,58\%. Aktivitas siswa yang menonjol yang dilakukan pada pertemuan kedua adalah mengidentifikasi variabel manipulasi, variabel respon, variabel kontrol 11,67\%, mengumpulkan data dengan melakukan percobaan $17,92 \%$, menganalisis data $17,92 \%$, merumuskan kesimpulan 6,67\%, mempresentasikan hasil kelompok dalam diskusi kelas 8,54\%, melibatkan diri dalam kegiatan diskusi kelas 9,17\%, dan bertanya pada guru $8,75 \%$. Sedangkan aktivitas siswa yang menonjol yang dilakukan pada pertemuan ketiga adalah mengidentifikasi variabel manipulasi, variabel respon, variabel kontrol 12,29\%, mengumpulkan data dengan melakukan percobaan $17,71 \%$, menganalisis data $17,81 \%$, merumuskan kesimpulan $6,35 \%$, mempresentasikan hasil kelompok dalam diskusi kelas 
$10,00 \%$, melibatkan diri dalam kegiatan diskusi kelas $8,96 \%$, dan bertanya pada guru 7,29\%. Persentase aktivitas siswa dalam mengidentifikasi variabel manipulasi, variabel respon, variabel kontrol pada pertemuan kedua adalah $11,67 \%$, sedangkan pada pertemuan ketiga mengidentifikasi variabel manipulasi, variabel respon, variabel kontrol 12,29\%.

Pada kegiatan ini siswa aktif dan berusaha mengidentifikasi variabel manipulasi, variabel respon, variabel kontrol. Pada tahap ini siswa masih banyak membutuhkan bimbingan karena mereka merasa masih baru pertama melaksanakan pembelajaran dengan model inkuiri. Namun pada pertemuan ketiga siswa sudah mulai terbiasa dan dapat melaksanakannya dengan tertib walaupun masih membutuhkan bimbingan.

Bimbingan dilakukan agar variabel manipulasi, variabel respon, variabel kontrol yang dibuat sesuai dengan tujuan pembelajaran. Hal ini sesuai teori yang dikemukakan Jerome Bruner bahwa siswa belajar melalui keterlibatan aktif dengan konsep-konsep dan prinsip-prinsip, sedangkan guru berperan mendorong siswa untuk mendapatkan pengalaman yang memungkinkan siswa untuk menemukan pengetahuan untuk diri mereka sendiri (Nur, 1998). Selain itu, penggunaan model inkuiri pada pembelajaran ini memiliki keterkaitan dengan pembelajaran penemuan, berorientasi pada keterampilan proses sains, dan siswa membangun pengetahuannya sendiri.

Hal ini diperkuat dengan pendapat Nur (2008) bahwa RPP yang dikembangkan dengan berbasis teori belajar yang tepat, penggunaan strategi dan model pembelajaran yang bervariasi akan mengaktifkan peserta didik. Pada pertemuan kedua tahap mengumpulkan data dengan melakukan percobaan $17,92 \%$ dan menganalisis data $17,92 \%$. Pada pertemuan ketiga tahap mengumpulkan data dengan melakukan percobaan $17,71 \%$, menganalisis data $17,81 \%$. Peningkatan aktivitas siswa tahap ini dikarenakan pada pertemuan ketiga siswa sangat antusias untuk melakukan praktikum dengan simulasi PhET, dan mereka kadang harus mengulang kegiatan yang sama beberapa kali karena mereka ingin mendapatkan hasil terbaik.

Antusiasme siswa ini sangat menguntungkan, karena dengan banyak berlatih menjalankan simulasi PhET siswa akan semakin terlatih untuk memiliki pola berfikir kontruktivisme, dimana siswa dapat menggabungkan pengetahuan awal dengan temuantemuan virtual darisimulasi yang dijalankan dan akan dapat menjadikan pemahaman yang baik tentang obesitas. Hal ini sesuai dengan hasil penelitian yang dilakukan oleh Finkelstein, dkk. (2004) bahwa siswa yang menggunakan simulasi komputer memiliki pemahaman yang paling unggul secara konseptual.

Berdasarkan pemaparan di atas, terlihat bahwa aktivitas siswa selama proses pembelajaran menggambarkan aktivitas siswa yang sesuai dengan tahap-tahap pembelajaran inkuiri yaitu pembelajaran yang menerapkan pendekatan pembelajaran aktif (student-centered), proses pembelajarannya mampu menumbuhkan dan mengembangkan daya kreasi, inovasi, nalar, dan kemampuan bereksperimen. Namun demikian beberapa siswa masih ada yang belum terlibat secara aktif dalam pembelajaran hal ini terekam dari adanya aktivitas siswa yang tidak relevan pada pertemuan $1(1,98 \%)$, pada pertemuan $2(1,35 \%)$ dan pada pertemuan $3(1,35 \%)$

Pembelajaran inkuiri menekankan pada keterlibatan aktif siswa dalam kegiatan pembelajaran. Pendekatan inkuiri merupakan pendekatan pengajaran yang mendorong siswa untuk menemukan prinsipprinsip untuk mereka sendiri, sehingga siswa akan termotivasi dalam belajar. Hal ini sesuai dengan pendapat Carin (1993) bahwa siswa akan lebih termotivasi jika di dalam belajar mereka menemukan sesuatu oleh mereka sendiri dibandingkan jika mereka hanya mendengarkan

materi pembelajaran. Keterlibatan siswa yang tinggi dalam pembelajaran sejalan dengan pernyataan Piaget yang menjelaskan bahwa pedagogi yang baik itu harus melibatkan penyodoran berbagai situasi di mana anak bisa bereksperimen, dalam arti luas mengujicobakan berbagai hal untuk melihat apa yang terjadi, memanipulasi benda-benda; memanipulasi simbol-simbol; melontarkan pertanyaan dan mencari jawabannya sendiri; merekonsiliasikan apa yang ditemukannya pada suatu waktu dengan apa yang ditemukannya pada waktu yang lain; membandingkan temuannya dengan temuan anak lain (Arends, 2007).

Menurut Piaget perkembangan kognitif sebagian besar bergantung kepada seberapa jauh anak aktif memanipulasi dan aktif berinteraksi dengan lingkungannya (Slavin, 1994). Dengan memperhatikan aktivitas siswa dalam pembelajaran sebagaimana diuraikan di atas, dapat dikatakan bahwa pembelajaran inkuiri yang telah dikembangkan peneliti dapat memfasilitasi siswa untuk terlibat aktif dan berinteraksi dengan lingkungannya, khususnya dengan berbagai sumber belajar yang tersedia. Keterlibatan siswa secara aktif di dalam pembelajaran ini berdampak pada peningkatan hasil belajar siswa baik pada kognitif maupun keterampilan proses sebagaimana telah diuraikan sebelumnya.

Rata-rata nilai uji awal (pretest) kognitif siswa pada uji coba 1 hanya sebesar 48,67 setelah dilakukan pembelajaran inkuiri rata-rata nilai uji akhir (posttest) 
kognitif siswa pada uji coba 1 dapat mencapai 90,67. Sedangkan pada uji coba 2 rata-rata nilai uji awal (pretest) kognitif siswa hanya sebesar 47,78 setelah dilakukan pembelajaran inkuiri rata-rata nilai uji akhir (posttest) kognitif siswa pada uji coba 2 dapat mencapai 91,11 . Tidak ada siswa yang tuntas pada saat pelaksanaan pretest di sebabkan karena siswa sama sekali belum memiliki tentang pengetahuan yang akan dipelajari. Sehingga jawaban yang mereka berikan pada soal pretest hanyalah secara spekulasi saja. Meskipun siswa berpikir secara serius dan sungguh-sungguh mereka tetap tidak bisa mengerjakan soal tersebut. Kondisi ini berbeda pada saat pelaksanaan posttest.

Indeks N-Gain THB kognitif 0,82. Berdasarkan kriteria N-Gain yang ditetapkan Hake (1999) jika NGain berada di atas $>0,70$ termasuk kategori tinggi. Dengan demikian dapat dikatakan bahwa pembelajaran model inkuiri dapatmeningkatkan hasil belajar siswa karena berada pada kategori tinggi. Hasil analisis data menunjukkan bahwa penerapan pembelajaran menggunakan perangkat pembelajaran model inkuiri untuk melatihkan keterampilan proses dapat menuntaskan seluruh indikator aspek kognitif dengan proporsi jawaban siswa pada masing-masing indikator $\geq 81 \%$.

Berdasarkan hasil analisis sensitivitas butir soal diketahui bahwa seluruh butir soal sensitif terhadap efek pembelajaran $(100 \%)$ karena memiliki indeks sensitivitas $\geq 0,30$. Butir soal yang memiliki nilai sensitivitas 0 memiliki harga tidak sensitif dan dinyatakan bahwa soal tersebut masih lemah dalam mengukur efek pembelajaran dan memerlukan revisi. Jika nilai sensitivitas 1 , maka soal sangat sensitif dapat dipakai dan dapat digunakan untuk mengukur efek pembelajaran. Rata-rata butir soal yang digunakan dalam penelitian ini termasuk sensitif untuk mengukur efek dari pembelajaran. Menurut Ibrahim (2005), soal yang sensitif dapat memberikan informasi bahwa hasil pengukuran merupakan akibat dari pembelajaran yang dilakukan.

Hasil penilaian keterampilan proses dapat menuntaskan semua indikator dengan proporsi jawaban siswa $\geq 81 \%$. Keterampilan proses siswa dalam merumuskan hipotesis (21.a), mengidentifikasi variabel manipulasi (21.b.1), mengidentifikasi variabel respon (21.b.2), merumuskan kesimpulan (21.e) menunjukkan proporsi butir soal pada U1 adalah 0,00 . Data ini menunjukkan bahwa siswa belum menguasai keterampilan proses (merumuskan hipotesis, mengidentifikasi variabel manipulasi, mengidentifikasi variabel respon, merumuskan kesimpulan).

Hal ini dikarenakan siswa belum pernah mengetahui dan belum pernah dilatih guru tentang keterampilan proses tersebut. Sedangkan proporsi butir soal pada U2 menjadi 1,00. Ini berarti bahwa siswa telah dapat menguasai keterampilan proses setelah guru melatihkan keterampilan proses melalui pembelajaran inkuiri pada materi sistem pencernaan pada manusia. Pada soal 21.d proporsi butir soal pada U1 menunjukkan angka 0,40 hal ini dikarenakan siswa hanya disuruh menyebutkan warna dari beberapa bahan praktikum (kanji, susu, minyak goreng dan kentang) sehingga tanpa diajari sebelumnya, siswa sudah mengetahui warna dari bahan-bahan tersebut. Sedangkan proporsi butir soal pada U2 menjadi 1,00 .

Pada soal 22.a.1 (mengidentifikasi variabel manipulasi), 22.a.2 (mengidentifikasi variabel respon), 22.a.3 (mengidentivikasi variabel kontrol), 22.c (melaksanakan eksperimen dan membuat tabel hasil pengamatan), 22.d (membuat/menggambar grafik) dan 22.e (merumuskan kesimpulan) menunjukkan proporsi butir soal pada $\mathrm{U} 1$ adalah 0,00 . Ini menunjukkan bahwa pada U1 siswa belum menguasai keterampilan proses (merumuskan kesimpulan) karena siswa belum pernah mengetahui dan belum pernah dilatih guru tentang keterampilan proses tersebut. Sedangkan pada soal 22.e (merumuskan kesimpulan) menunjukkan proporsi butir soal pada U2 menjadi 1,00. Ini berarti bahwa siswa telah dapat menguasai keterampilan proses (merumuskan kesimpulan) setelah guru melatihkan keterampilan proses melalui pembelajaran inkuiri pada materi sistem pencernaan pada manusia.

Rata-rata nilai nilai uji awal (pretest) keterampilan proses siswa pada uji coba 1 hanya sebesar 17,96 dan rata-rata nilai nilai uji awal (pretest) keterampilan proses siswa pada uji coba 2 hanya sebesar 17,46. Pada uji awal (pretest) semua siswa tidak ada yang tuntas. Ini sejalan dengan temuan Nur, dkk (2010) bahwa siswasiswa SMP dan SMA yang diukur keterampilan prosesnya dengan TKPS (Tes Keterampilan Proses Sains) Format B, belum terampil dalam tugas perencanaan eksperimen, membuat tabel data dan grafik, perumusan variabel eksperimen, dan perumusan definisi operasional variabel.

Rata-rata nilai uji akhir (posttest) keterampilan proses siswa pada uji coba 1 setelah dilakukan pembelajaran inkuiri untuk melatihkan keterampilan proses dapat mencapai 93,39 sedangkan rata-rata nilai uji akhir (posttest) keterampilan prosessiswa pada uji coba 2 setelah dilakukan pembelajaran inkuiri untuk melatihkan keterampilan proses dapat mencapai 93,73.

Pencapaian hasil belajar siswa (keterampilan proses) ini merupakan dampak dari pembelajaran inkuiri yang dilakukan. Terbukti baik pada uji coba 1 maupun uji coba 2 Indeks N-Gain THB proses mencapai 0,92. Berdasarkan kriteria N-Gain yang ditetapkan Hake (1999) jika N-Gain berada di atas $>0,70$ termasuk kategori tinggi. Berdasarkan data 
tersebut maka dapat dikatakan bahwa pembelajaran model inkuiri dapat melatihkan keterampilan proses siswa.

Hal ini berhubungan dengan respon siswa yang menyatakan $80 \%$ bertarik dengan pembelajaran model inkuiri untuk melatihkan keterampilan proses. Siswa merasa mudah dalam hal merumuskan masalah 90\%, merumuskan hipotesis $90 \%$, menentukan variabel manipulasi $80 \%$, menentukan variabel respon $80 \%$, menentukan variabel kontrol $80 \%$, mengumpulkan data dengan melakukan percobaan $80 \%$, menganalisis data hasil percobaan $70 \%$, dan merumuskan kesimpulan hasil percobaan 90\%. Kemudahan-kemudahan yang dirasakan siswa tersebut menjadi salah satu faktor yang menarik dalam kegiatan pembelajaran.

Siswa menyatakan pembelajaran model inkuiri untuk melatihkan keterampilan proses merupakan hal baru bagi siswa 90\%. Ketertarikan dan kebaharuan ini akan menjadi faktor pendorong (motivasi) bagi siswa untuk memperoleh hasil yang baik dalam pembelajaran. Menurut Eggen dan Kauchak (2012), murid yang termotivasi secara ekstrinsik belajar keras untuk menghadapi suatu tes karena mereka yakin bahwa belajar akan membuahkan skor tes yang tinggi atau pujian dari guru, sementara motivasi secara intrinsik mendorong murid untuk belajar karena mereka ingin memahami isi pelajaran dan memandang pembelajaran itu bernilai bagi diri mereka.

Soal dikatakan sensitif jika memiliki harga sensitivitas $\geq 0,30$ (Gronlund, 1982). Berdasarkan hasil analisis sensitivitas butir soal diketahui bahwa sensitivitas butir soal berada antara 0,30 sampai dengan 1,00. Ini termasuk kategori peka terhadap efek pembelajaran. Menurut Ibrahim (2005), soal yang sensitif dapat memberikan informasi bahwa hasil pengukuran merupakan akibat dari pembelajaran yang dilakukan.

Rata-rata hasil keterampilan psikomotor siswa dalam menggunakan simulasi PhET pada uji coba 1 (pertemuan ketiga) adalah 94,7. Rata-rata hasil keterampilan psikomotor siswa dalam menggunakan simulasi PhET pada pertemuan ketiga pada uji coba 2 adalah 93,00. Hal ini terjadi karena media simulasi PhET yang digunakan dalam pembelajaran sudah menyajikan data yang sangat jelas, sehingga siswa tidak mengalami kesulitan untuk membaca dan menuliskannya ke dalam tabel. Selama kegiatan praktikum guru selalu memberikan bimbingan untuk memastikan bahwa yang dikerjakan siswa adalah benar sehingga diharapkan nantinya siswa tidak salah dalam penerapan konsep.

Hal ini sesuai dengan pendapat Kardi (2013) bahwa guru melakukan bimbingan belajar untuk memastikan agar siswa benar pada saat dia menerapkan konsep atau keterampilan yang baru.

Persentase respon siswa terhadap materi/isi pelajaran 80\%, Bahan Ajar Siswa (BAS) dan Lembar Kegiatan Siswa (LKS) 90\%, penerapan model pembelajaran inkuiri untuk melatihkan keterampilan proses $80 \%$, penggunaan program simulasi PhET dalam proses pembelajaran $100 \%$.

Tingginya ketertarikan siswa terhadap materi/isi pelajaran karena materi yang diajarkan berkaitan erat dengan kehidupan sehari-hari siswa. Tingginya ketertarikan siswa terhadap BAS dan LKS karena siswa menganggap BAS $80 \%$ baru dan LKS $100 \%$ baru. Dengan respon yang demikian itu, akan menimbulkan rasa ingin tahu yang tinggi pada diri siswa untuk menggunakan BAS dan LKS dalam aktivitas belajarnya. Menurut Frandsen (dalam Suryabrata, 2006), salah satu aspek yang dapat menimbulkan motivasi belajar pada diri siswa adalah rasa ingin tahu dan ingin menyelidiki dunia yang lebih luas. Sifat ingin tahu mendorong seseorang untuk belajar, sehingga setelah mereka mengetahui segala hal yang sebelumnya tidak diketahui maka akan menimbulkan kepuasan tersendiri pada dirinya.

Respon positif siswa terhadap penggunaan program simulasi PhET dalam pembelajaran menunjukkan pentingnya peran media dalam menunjang keberhasilan proses belajar mengajar. Oleh karena itu, guru perlu menggunakan media secara optimal. Upaya optimalisasi penggunaan media ini mempunyai arti penting dalam rangka meningkatkan mutu proses belajar mengajar di kelas. Dengan optimalisasi penggunaan media ini diharapkan baik proses maupun hasil belajar siswa dapat meningkat (Setyowati, dkk., 1996:34).

Pembelajaran dengan multimedia ditekankan pada kemajuan teknologi komputer yang dipadukan dan disesuaikan dengan kurikulum (Heinich, et al., 1999:208). Penggunaan media yang tepat dalam pembelajaran diharapkan dapat memberikan manfaat bagi siswa khususnya untuk membantu siswa dalam memahami materi pelajaran sehingga hasil belajar siswa dapat meningkat. Hal ini sesuai dengan hasil penelitian Basri (2003) dan Suwarna (2007) yang menyebutkan bahwa pembelajaran dengan media interaktif dapat meningkatkan hasil belajar siswa.

Suasana belajar yang menyenangkan akan membuat siswa dapat menerima pelajaran dengan baik. Berdasarkan data yang diperoleh bahwa pembelajaran sangat menarik bagi siswa, terbukti $80 \%$ siswa menyatakan tertarik dengan suasana belajar dan cara guru mengajar.

Hal ini diperkuat oleh data bahwa 90\% siswa menyatakan berminat mengikuti pembelajaran seperti 
ini pada topik-topik pembelajaran yang lain. Hal ini mengindikasikan bahwa penerapan pembelajaran model inkuiri untuk melatihkan keterampilan proses membuat siswa tertarik dan antusias mengikuti pembelajaran model inkuiri yang dilaksanakan. Cara mengajar guru mendapat respon positif dari siswa. Sebanyak $80 \%$ siswa tertarik dengan cara guru mengajar. Siswa juga merasa mudah ketika mendapat penjelasan guru saat kegiatan pembelajaran berlangsung yaitu sebesar 90\%, dan $90 \%$ siswa berpendapat mudah saat guru memberikan bimbingan kepada siswa untuk menemukan konsep melalui eksperimen. Hal ini menunjukkan bahwa tahapan pembelajaran model inkuiri menarik bagi siswa. Dengan respon positif yang tinggi terhadap cara mengajar guru, diharapkan hasil belajar terutama pemahaman konsep siswa dapat meningkat.

Komponen keterampilan proses sains yang dilatihkan guru dengan menggunakan pembelajaran inkuiri juga tergolong baru, yaitu menentukan variabel manipulasi $90 \%$, menentukan variabel respon $90 \%$, dan menentukan variabel kontrol 90\%. Komponen keterampilan proses sains yang dilatihkan guru dengan menggunakan pembelajaran inkuiri yang tergolong tidak baru, yaitu merumuskan masalah, merumuskan hipotesis, mengumpulkan data dengan melakukan percobaan, menganalisis data hasil percobaan dan merumuskan hasil percobaan. Hal ini menunjukkan bahwa siswa tidak asing lagi dengan beberapa keterampilan proses di atas, karena selama ini siswa telah diajarkan keterampilan proses tersebut melalui kegiatan eksperimen di laboratorium dengan menggunakan LKS yang disusun oleh MGMP Kabupten Lamongan sehingga memudahkan siswa dalam mengikuti proses belajar mengajar.

Selama pembelajaran model inkuiri untuk melatihkan keterampilan proses siswa merasa mudah dalam hal merumuskan masalah 90\%, merumuskan hipotesis $90 \%$, menentukan variabel manipulasi $90 \%$, menentukan variabel respon $90 \%$, dan menentukan variabel kontrol $90 \%$. mengumpulkan data dengan melakukan percobaan $80 \%$, menganalisis data hasil percobaan $70 \%$, dan merumuskan kesimpulan hasil percobaan 90\%. Kebaharuan dan kemudahan yang dirasakan siswa terhadap komponen-komponen keterampilan proses yang dilatihkan tersebut berdampak pada tumbuhnya minat dan motivasi belajar siswa, yang akhirnya berdampak pula pada hasil belajar siswa.

Berdasarkan pemaparan di atas, diketahui bahwa secara keseluruhan siswa memberikan respon positif terhadap pembelajaran Respon positif ini menunjukkan bahwa siswa antusias dengan pembelajaran yang disajikan. Hal ini dapat memotivasi siswa untuk meningkatkan perhatian dan membuat mereka terlibat dalam pengalaman pembelajaran yang menyenangkan dan bermakna (Nur, 2008).

Secara umum penerapan pembelajaran dapat berjalan dengan baik, namun masih terdapat hambatan dalam pembelajaran, yaitu siswa belum terbiasa dengan model pembelajaran inkuiri sehingga membutuhkan waktu yang lebih lama untuk menyelesaikan kegiatan eksperimen. Adanya hambatan ini menyebabkan waktu KBM melebihi alokasi waktu yang direncanakan dalam RPP namun secara umum kemandirian siswa pada pertemuan ketiga lebih baik dari pada pertemuan kedua. Adapun temuan peneliti sebagai berikut:

1. Kualitas perangkat pembelajaran yang meliputi Silabus, Rencana Pelaksanaan Pembelajaran (RPP), Lembar Kerja Siswa (LKS), Bahan Ajar Siswa (BAS), Lembar Penilaian Tes Hasil Belajar (THB) Produk dan THB Keterampilan Proses, secara keseluruhan dikategorikan baik dan layak untuk digunakan sebagai perangkat pembelajaran di kelas.

2. Keterlaksanaan perangkat pembelajaran dari ketiga Rencana Pelaksanaan Pembelajaran (RPP 1, RPP 2, dan RPP 3) yang telah diimplementasikan dikategorikan baik dengan reliabilitas instrumen yang bersifat reliabel dan persentase keterlaksanaannya $100 \%$.

3. Aktivitas siswa selama penerapan perangkat pembelajaran yang dikembangkan menggambarkan aktivitas siswa yang sesuai dengan langkah-langkah dalam pembelajaran inkuiri.

4. Respon siswa dikategorikan baik karena metode pembelajaran ini merupakan hal yang baru dan menyenangkan. Ini menunjukkan respon positif terhadap kegiatan pembelajaran biologi yang dikembangkan dengan model inkuiri untuk melatihkan keterampilan proses pada materi sistem pencernaan manusia.

5. Ketuntasan hasil belajar siswa setelah dilakukan pembelajaran menggunakan perangkat pembelajaran yang dikembangkan menunjukkan bahwa hasil belajar siswa dinyatakan tuntas. Nilai Tes Hasil Belajar (THB) siswa menunjukkan peningkatan dari nilai pretest ke nilai posttest untuk semua indikator pembelajaran, ini menunjukkan bahwa perangkat pembelajaran yang dikembangkan dapat meningkatkan hasil belajar siswa, menuntaskan semua indikator pembelajaran dan dapat melatihkan keterampilan proses.

6. Kendala-kendala yang ditemukan di lapangan, antara lain: Siswa belum terbiasa mengikuti pembelajaran inkuiri yang berbasis eksperimen, sehingga waktu yang digunakan untuk membimbing melebihi waktu yang telah ditentukan dalam RPP.

Siswa belum terbiasa dengan keterampilan proses sains dalam pembelajaran, khususnya kemampuan menentukan variabel respon, variabel manipulasi dan 
variabel kontrol karena kemampuan keterampilan proses tersebut relatif baru dan sulit dipahami.

\section{KESIMPULAN}

\section{A. Simpulan}

Berdasarkan hasil penelitian disimpulkan bahwaPerangkat pembelajaran biologi yang dikembangkan dengan model inkuiri, yang terdiri dari: Silabus, Rencana Pelaksanaan Pembelajaran (RPP), Lembar Kerja Siswa (LKS), Bahan Ajar Siswa (BAS), Lembar Penilaian yang telah dikembangkan valid, praktis dan efektif untuk melatihkan keterampilan proses pada materi sistem pencernaan manusia

B. Saran

1. Mengingat kendala yang dihadapi dalam pembelajaran inkuiri yang berbasis eksperimen adalah masalah waktu, guru dapat mengantisipasinya dengan: (1) kegiatan pembelajaran yang diterapkan diatur secara ketat, dan (2) peralatan dan media yang digunakan dipersiapkan dengan baik.

2. Perlu dilakukan latihan yang lebih intensif pada aspek-aspek keterampilan proses sains dalam pembelajaran, khususnya kemampuan menentukan variabel respon, variabel manipulasi dan variabel kontrol sehingga kemampuan keterampilan proses tersebut lebih mudah dipahami siswa.

\section{REFERENSI}

Arends, R. I. (2012). Learning To Teach. Ninth Edition. New York: McGraw-Hill Companies, Inc.

Arikunto, S. (2010). Prosedur Penelitian Suatu Pendekatan Praktik. Jakarta: Rineka Cipta.

Carin, A. A. (1993). Teaching Modern Science. Sixth Edition. New York: Merril, An Imprint of Macmillan Publishing Company.

Collette, A.T. dan Chiapetta, E.L. (1994). Science Instruction in The Middle and Secondary Schools.. New York: Macmillan Publishing Company.

Depdiknas. (2007). Kurikulum Sekolah Menengah Pertama (SMP) Panduan Pengembangan Rencana Pelaksanaan Pembelajaran (RPP) Sekolah Menengah Pertama (SMP) Mata Pelajaran Ilmu Pengetahuan Alam. Jakarta: Depdiknas.

Depdiknas. (2007). Peraturan Pemerintah Republik Indonesia No. 19 Tahun 2005. tentang Standart Proses. Jakarta: Depdiknas.

Eggen, Paul. D., dan Kauchak, D. P. (2012). Strategies and Models for Teachers: Teaching Content and Thinking Skills, 6th Edition. Boston: Pearson Education Inc.
Finkelstein, N., Adams, W., Keller, C., Perkins, K., Wieman, C. and the PhET Team, (2006). "High-Tech Tools for Teaching Physics: the Physics Education Technology Project". Journal of Online Learning and Teachin., 2 , 109-121.

Gronlund, Norman. E., dan Linn, Robert. L. (1982). Measurement and Assessment, in Teaching 7th Edition. New Jersey: Prentice-Hall, Inc.

Gulo, W. (2002). Strategi Belajar Mengajar. Jakarta: PT. Grasindo.

Hake, R.R. (1999). American Educational Research Assosiation's Division D, Measurement and Research Methodology. Analyzing Change/Gain Score. USA: Woodland Hills.

Heinich, R., Molenda, M., Russel, J.D. (1999). Instructional Media and Technologies for Learning. New York: Prentice-Hall, inc.

Ibrahim, M. (2005). Assesmen Berkelanjutan. Surabaya: Unesa University Press.

Indriani, D. (2013). Pembelajaran IPA Biologi SMP dengan Penggunaan Model Pembelajaran Inkuiri untuk Menuntaskan Hasil Belajar Siswa (Tesis Magister Pendidikan). Universitas Negeri Surabaya.

Joyce, W., Weil, M., and Calhoun, E. (2009). Models of Teaching 4th ed. Boston: Allyn and Bacon.

Kardi, S. (2003). Strategi Motivasi Model ARCS. Surabaya: Universitas Negeri Surabaya.

Krathwohl, D. R. (2002). "A Revision of Bloom's Taxonomy: An Overview". Theory Into Practice. Vol 41 No. 4 Autumn 2002. pp. 212 -218 .

Meador, (2010). Introduction to Inquiry Physics A Modified Learning Cycle Curriculum. Bartlesville: Bartlesville High School. http://inquiryphysics.org Diakses 14 Maret 2013.

National Reseach Council. (2000). Inquiry at The National Science Education Standards: A Guide for Teaching and Learning. Washington DC: National Academy Press.

Nieveen, N. (1999). Prototyping to reach product quality. In J. van den Akker, R.M. Branch, K. Gustafson, N. Nieveen, \& T. Plomp (Eds), Design approaches and tools in education and training. Boston: Kluwer Academic, 125-136.

Nur, M. (2008). Pengajaran Berpusat kepada Siswa dan Pendekatan Konstruktivis dalam Pengajaran. Edisi 5. Surabaya: Pusat Sains dan Matematika Sekolah Unesa.

Setyowati, N., Nursalim, M., Azizah, U., Johan, A., Andriana, A., Indana, S., Lestariadi, L. (1995). Optimalisasi Penggunaan Alat Peraga IPA 
dan IPS Sekolah Dasar di Surabaya. Jurnal Riset No. 05/Th.III/1995

Slavin, R. E. (1994). Educational Psychology: Theory and Practise. Massachusetts: Allyn and Bacon.

Suryabrata, S. (2006). Psikologi Pendidikan. Jakarta; PT Raja Grafindo Persada.
Thiagarajan, S. Semmel, D.S. and Semmel, M.I. (1974). Instructional Development for Training Teacher of Exceptional Children. Minepolish: Indiana University. 